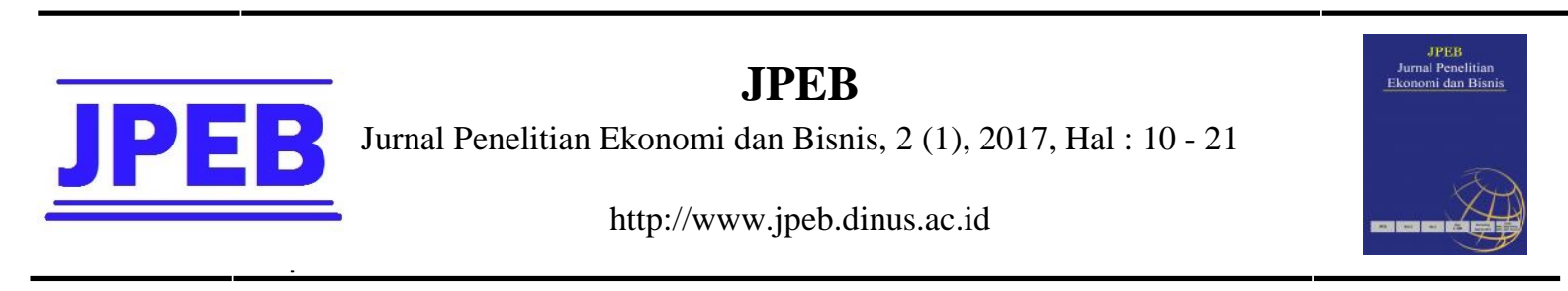

\title{
ANALISIS FAKTOR-FAKTOR YANG MEMPENGARUHI MINAT BELI ULANG PRODUK YOU C 1000 SERTA DAMPAKNYA TERHADAP LOYALITAS KONSUMEN
}

\author{
Dewi Sartika* \\ Magister Manajemen, Fakultas Ekonomi dan Bisnis ,Universitas Dian Nuswantoro \\ Jalan Imam Bonjol Nomor 207 Semarang 50131, Indonesia \\ *Corresponding Author: Dewisartika@gmail.com
}

Diterima : Desember 2016; Direvisi : Januari 2017; Dipublikasikan : Maret 2017

\begin{abstract}
The purpose of this research is to find factors affecting interest in buying repeated products You C 1000 and its impact on loyalty consumers. The research is research as the sintesa, namely research describing the objects of that deals through jurnal-jurnal appropriate. Sample in this research was 115 people who have been consume products Yои C 1000 more than once within the city of semarang by using Structural Equation Modeling ( SEM ).The results show quality products, promotion, the price, and interest in buying repeated have had a positive impact and significant impact on loyalty consumers, product quality also has not been affecting the loyalty consumers. The effects of quality products to interest in buying repeated indicated by value estimate of 0,300; the effect of a promotion to interest in buying repeated indicated by value estimate of 0,285; the effect the price of interest in buying repeated indicated by value estimate of 0,373; the effect interest in buying repeated to loyalty consumers indicated by value estimate of 0,457 .
\end{abstract}

Keywords : Quality Products; Promotion; Price; Interest In Buying Repeated; Loyalty Consumers

\begin{abstract}
ABSTRAK
Tujuan penelitian ini adalah untuk mengetahui faktor-faktor yang mempengaruhi minat beli ulang produk You C 1000 serta dampaknya terhadap loyalitas konsumen. Penelitian ini merupakan penelitian yang berjenis sintesa, yaitu penelitian yang menggambarkan obyek-obyek yang berhubungan melalui jurnal-jurnal yang sesuai. Sampel dalam penelitian ini adalah 115 orang yang pernah mengkonsumsi produk You C 1000 lebih dari sekali di kota Semarang dengan menggunakan Structural Equation Modeling (SEM).Hasilnya menunjukkan kualitas produk, promosi, harga, dan minat beli ulang berpengaruh positif dan signifikan terhadap loyalitas konsumen, kualitas produk juga tidak berpengaruh terhadap loyalitas konsumen. Efek dari kualitas produk terhadap minat beli ulang ditunjukkan dengan nilai estimate sebesar 0,300 ; efek dari promosi terhadap minat beli ulang ditunjukkan dengan nilai estimate sebesar 0,285 ; efek harga terhadap minat beli ulang ditunjukkan dengan nilai estimate sebesar 0,373 ; efek minat beli ulang terhadap loyalitas konsumen ditunjukkan dengan nilai estimate sebesar 0,457 .
\end{abstract}

Kata kunci : Kualitas Produk; Promosi; Harga; Minat Beli Ulang; Loyalitas Konsumen 


\section{PENDAHULUAN}

Minum merupakan hal yang penting bagi manusia karena sebagai salah satu cara mempertahankan hidup dan sekaligus menghilangkan rasa dahaga. Apalagi di negara yang mempunyai iklim tropis (panas) yang menyebabkan orang mudah kehilangan tenaga dan cairan, minuman sangat dibutuhkan oleh setiap orang dimana saja dan kapan saja, yang dapat menghilangkan rasa haus dan mengembalikan stamina yang hilang saat bekerja, dengan harga yang relatif terjangkau, yaitu : minuman ringan yang mengandung vitamin $\mathrm{C}$ dosis tinggi. Dari sekian banyak jenis minuman ringan yang ada dipasaran, kebiasaan meminum minuman yang bervitamin merupakan suatu kebudayaan yang terjadi di luar negeri namun mulai menjadi trend di negara ini. Karena rasanya yang pas dengan selera (taste) masyarakat Indonesia dan masyarakat umum juga beranggapan bahwa minuman bervitamin $\mathrm{C}$ dosis tinggi ini dapat memulihkan tenaga sehingga banyak masyarakat yang mengkonsumsi minuman bervitamin ini.

Saat ini masyarakat semakin sadar akan pentingnya kesehatan apalagi saat ini pola hidup masyarakat modern sudah semakin berubah dibandingkan dengan masa lalu. Kesibukan dinamika kehidupan modern membuat masyarakat tidak punya waktu untuk menjaga kesehatan apalagi untuk masyarakat perkotaan yang gaya hidupnya sering berisiko bagi terjadinya tingkat stress yang tinggi dan menurunnya kualitas nutrisi. Vitamin, khususnya vitamin C, merupakan satu zat yang diperlukan tubuh manusia setiap hari, sebagai antioksidan dan menjaga kekebalan tubuh terhadap berbagai penyakit. Vitamin $\mathrm{C}$ sebenarnya bisa ditemukan diberbagai jenis buah dan sayuran. Hanya saja, selain kadarnya yang kurang mencukupi, pola makan serta kesibukan masyarakat modern juga menjadikan kebutuhan vitamin $\mathrm{C}$ kurang terpenuhi. Pada penelitian ini akan dianalisis tentang minat beli ulang terhadap pembelian produk minuman You C 1000 yang terbuat dari berbagai jenis formula dan zat-zat yang ada di dalamnya. You C 1000 merupakan salah satu produk minuman yang mengandung vitamin C berbentuk cair. Merek You C 1000 memberikan nilai bagi konsumennya (brand value) antara lain dengan kandungan vitamin C sebesar $1000 \mathrm{mg}$, produk berbentuk cairan sehingga praktis bagi konsumen, rasa khas jeruk yang segar dan kemasan kaca yang mencerminkan kemewahan.

PT Djojonegoro merupakan anak perusahaan dari Orang Tua Group yang memperoleh lisensi dari Takeda Food Product Ltd Jepang. PT Djojonegoro merupakan produsen minuman kesehatan pada kategori minuman suplemen berenergi dengan kandungan vitamin $\mathrm{C}$ dosis tinggi dengan merek dagang You C 1000. You C 1000 mulai resmi memasuki pasar Indonesia pada awal tahun 2005, sebelumnya pada bulan September tahun 2004 sampai bulan januari 2005 produk ini diperkenalkan untuk wilayah Jakarta dan Bali dan mendapat sambutan positif. PT Djojonegoro menguasai pasar minuman suplemen berenergi, karena perusahaan pertama yang memproduksi minuman suplemen dengan kandungan vitamin $\mathrm{C}$ dosis tinggi dan soda dalam kemasan botol.

Pada akhir tahun 2006 muncul beberapa pesaing di industri minuman suplemen berenergi, antara lain seperti Redoxon, Holisticare Ester C, Xonce, Vitacimin, Vitalong C, Enervon $\mathrm{C}$ dan Vitalong $\mathrm{C}$. Tetapi produk - produk vitamin $\mathrm{C}$ tersebut berbeda dengan You $\mathrm{C}$ 1000, karena You C 1000 tidak memperlakukan produknya sebagai obat tetapi lebih sebagai minuman.

Masuknya beberapa pemain baru dalam industri minuman suplemen berenergi sebagai dampak besarnya peluang pertumbuhan terhadap permintaan menyebabkan persaingan semakin ketat. Persaingan ini tentu akan mempengaruhi penjualan PT Djojonegoro sebagai produsen pertama pada kategori minuman suplemen tersebut. Kondisi ini membuat PT Djojonegoro perlu menjaga loyalitas konsumen dengan cara memaksimalkan kinerja dari atribut-atribut produk mereka. 
Dewi Sartika : Analisis Faktor-Faktor Yang Mempengaruhi Minat Beli Ulang Produk You C 1000 Serta Dampaknya Terhadap Loyalitas Konsumen

Berdasarkan Top Brand Index (TBI) minuman suplemen tahun 2015, You C 1000 menempati posisi ketiga dibawah Vitacimin dan Xon-Ce dengan Top Brand Index sebesar 10,2\%. Walaupun You C 1000 masuk kategori TOP, tetapi masih kalah apabila dibandingkan dengan Vitacimin dan Xon-Ce

Tabel 1. Top Band Index (TBI) Minuman Suplemen Tahun 2015

\begin{tabular}{lcc}
\hline \multicolumn{1}{c}{ Merk } & TBI & Kategori \\
\hline Vitacimin & $40,4 \%$ & TOP \\
Xon-Ce & $10,7 \%$ & TOP \\
You C 1000 & $10,2 \%$ & TOP \\
Redoxon & $10,1 \%$ & \\
Enervon C & $10,1 \%$ & \\
Vicee & $8,1 \%$ & \\
Vitalong C & $3,5 \%$ & \\
\hline
\end{tabular}

Selain TBI yang masih kalah dibandingkan merk lain, penjualan You C 1000 di Kota Semarang mengalami fluktuasi. Hal tersebut bisa dilihat pada gambar di bawah ini:

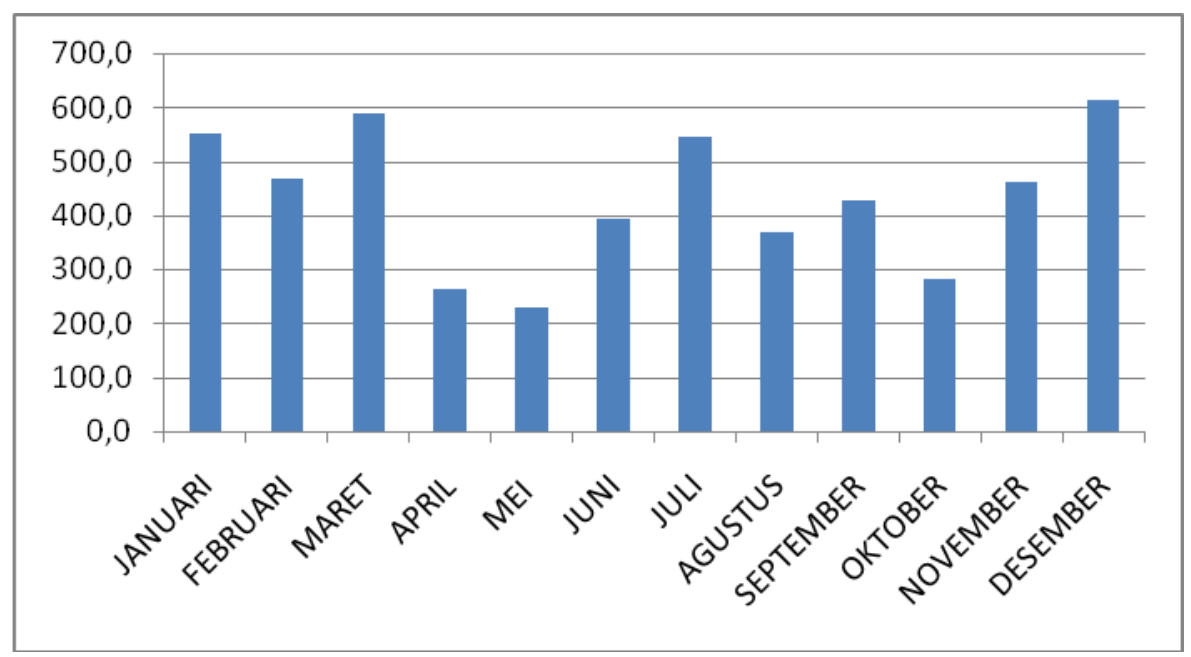

Gambar 1. Penjualan You C 100 di Kota Semarang

Pada era globalisasi ini tiap perusahaan dituntut untuk bisa mempertahankan kelangsungan perusahaannya. Untuk memenangkan persaingan pasar harus digunakan perencanaan pemasaran strategis yang berorientasi pasar. Proses perencanaan pemasaran dimulai dengan kegiatan analisis lingkungan, pasar, dan situasi persaingan yang akan menghasilkan gambaran tentang berbagai potensi pasar yang terbuka untuk dilayani beserta tinggi rendahnya tingkat persaingan bagi masing-masing potensi pasar tersebut. Potensi yang dicari tentunya potensi yang besar dengan tingkat persaingan yang rendah, dimana hal ini merupakan sasaran atau target pasar yang akan menjadi pilihan.

Target pasar yang dipilih tidak lebih dari satu sasaran dan selanjutnya mengenai program pemasaran bisa dilakukan dengan memakai konsep marketing mix (bauran pemasaran) yaitu terdiri atas produk, harga, promosi dan tempat. (Kotler \& Keller 2009 : 76) mengatakan bauran pemasaran adalah adalah seperangkat alat pemasaran yang dapat 
dikendalikan, yang diterapkan ke produk dari perusahaan itu sendiri untuk menghasilkan respon yang diinginkan terhadap pasar. Bauran pemasaran merupakan alat bagi pemasar yang terdiri dari berbagai elemen suatu program pemasaran yang perlu dipertimbangkan agar implementasi strategi pemasaran dan positioning yang ditetapkan dapat berjalan sukses. (Lupiyoadi, 2001 : 58). Tujuan pemasaran adalah untuk memenuhi dan memuaskan kebutuhan serta keinginan pelanggan sasaran, oleh karena itu perlu dipelajari bagaimana karakteristik pembeli individu, kelompok dan organisasi dalam memilih, membeli, memakai serta memanfaatkan produk dan jasa dalam rangka memuaskan kebutuhan dan hasrat mereka. Perusahaan harus melakukan upaya-upaya yang kreatif, inovatif sehingga produknya menjadi pilihan dari banyak pelanggan yang nantinya diharapkan menjadi pelanggan yang loyal.

Oliver mengatakan loyalitas pelanggan adalah komitmen pelanggan bertahan secara mendalam untuk berlangganan kembali atau melakukan pembelian ulang produk / jasa terpilih secara konsisten dimasa yang akan datang, meskipun pengaruh situasi dan usahausaha pemasaran mempunyai potensi untuk menyebabkan perubahan perilaku (Ratih, 2005). Dengan memiliki konsumen yang setia, perusahaan akan mendapatkan sejumlah keuntungan. Sebelum menjadi loyal, pelanggan biasanya cenderung memiliki minat untuk membeli produk tersebut secara berulang-ulang.

Minat beli adalah tahap kecenderungan responden untuk bertindak sebelum keputusan membeli benar-benar dilaksanakan (Kurniawan, dkk, 2008). Minat beli diperoleh dari suatu proses belajar dan proses pemikiran yang membentuk suatu persepsi (Kristiana dan Wahyudin, 2012). Berdasarkan penelitian Kurniawan dkk (2008), Rizana dan Rizki (2013), Rizky dkk (2014), Cahya dkk (2012) dan Kristiana dan Wahyudin (2012), beberapa faktor yang mempengaruhi minat beli antara lain kualitas produk, harga dan promosi. Sementara berdasarkan penelitian Kurniawan dkk (2008) serta Rizana dan Rizki (2013), minat beli ulang mempengaruhi loyalitas konsumen

Pemilihan wilayah serta studi kasus didasarkan pada pertimbangan bahwa Semarang merupakan ibu kota Jawa Tengah, penduduknya terbanyak dan terpadat dibandingkan dengan kota-kota lain di Jawa Tengah. Tentunya dengan penduduk yang terbanyak memungkinkan menjadi sasaran utama pemasaran minuman sehingga kemungkinan sebagian besar penduduknya juga sudah mengkonsumsi minuman You C 1000.

Tujuan penelitian ini adalah untuk menganalisis pengaruh kualitas produk, harga dan promosi terhadap minat beli ulang produk You C 1000 serta menganalisis pengaruh minat beli ulang produk You C 1000 terhadap loyalitas konsumen.

\section{TINJAUAN PUSTAKA \\ Loyalitas Konsumen}

Menurut Griffin, loyalitas lebih mengacu pada wujud perilaku dari unit-unit pengambilan keputusan untuk melakukan pembelian secara terus-menerus terhadap barang atau jasa suatu perusahaan yang dipilih (Ratih, 2005).

Loyalitas pelanggan menunjukkan perilaku yang dimaksud berkaitan dengan produk dan jasa. Hal ini termasuk kemungkinan pembelian mendatang atau pembaharuan kontrak jasa atau sebaliknya, seberapa mungkin pelanggan akan beralih ke penyedia jasa atau merek lain. Pelanggan mungkin menjadi loyal karena hambatan peralihan yang tinggi berkaitan dengan faktor-faktor teknis, ekonomis dan psikologis yang menjadikannya mahal atau sulit bagi pelanggan untuk mengubah pemasok. Pelanggan juga dapat menjadi loyal karena puas dengan pemasok atau merek produk, daya tahannya, perusahaan cenderung mendekati kepuasan sebagai strategi yang potensial dalam jangka panjang.

Pelanggan yang loyal merupakan aset penting bagi perusahaan, hal ini dapat dilihat dari karakteristik yang dimilikinya, sebagaimana diungkapkan Griffin pelanggan yang loyal memiliki karakteristik sebagai berikut (Ratih, 2005) : 
Dewi Sartika : Analisis Faktor-Faktor Yang Mempengaruhi Minat Beli Ulang Produk You C 1000 Serta Dampaknya Terhadap Loyalitas Konsumen

1. Melakukan pembelian secara teratur

2. Membeli diluar produk lini produk / jasa

3. Merekomendasikan produk lain

4. Menunjukkan kekebalan dari daya tarik produk sejenis dari pesaing

Seorang konsumen yang sudah sangat sering melakukan pembelian terhadap merek tertentu, maka dia tidak lagi mempertimbangkan untuk membeli merek lain. Jika ada konsumen dalam pembeliannya berperilaku seperti itu, maka bisa dikatakan bahwa konsumen itu sangat loyal terhadap merek pilihannya dan itulah yang disebut loyalitas konsumen.

\section{Minat Beli}

Minat beli adalah tahap kecenderungan responden untuk bertindak sebelum keputusan membeli benar-benar dilaksanakan. Terdapat perbedaan antara pembelian aktual dan minat pembelian. Bila pembelian aktual adalah pembelian yang benar-benar dilakukan oleh konsumen, maka minat pembelian adalah niat untuk melakukan pembelian pada kesempatan mendatang. Meskipun merupakan pembelian yang belum tentu akan dilakukan pada masa mendatang namun pengukuran terhadap minat pembelian umumnya dilakukan guna memaksimumkan prediksi terhadap pembelian aktual itu sendiri. (Iwan dkk, 2008).

Definisi minat beli menurut Thamrin (2003 : 142) adalah merupakan bagian dari komponen perilaku konsumen dalam sikap mengkonsumsi, kecenderungan responden untuk bertindak sebelum keputusan membeli benar-benar dilaksanakan. Dapat dikatakan bahwa minat beli merupakan pernyataan mental dari konsumen yang merefleksikan rencana pembelian sejumlah produk dengan merek tertentu. Hal ini sangat diperlukan oleh para pemasar untuk mengetahui minat beli konsumen terhadap suatu produk, baik para pemasar maupun ahli ekonomi menggunakan variabel minat untuk memprediksi perilaku konsumen di masa yang akan datang.

Suatu produk dapat dikatakan telah dikonsumsi oleh konsumen apabila produk tersebut telah diputuskan untuk dibeli. Keputusan untuk membeli dipengaruhi oleh nilai produk yang dievaluasi. Bila manfaat yang dirasakan lebih besar dibandingkan pengorbanan untuk mendapatkannya, maka dorongan untuk membelinya semakin tinggi. Sebaliknya bila manfaatnya lebih kecil dibandingkan pengorbanannya maka biasanya pembeli akan menolak untuk membeli dan pada umumnya beralih mengevaluasi produk lain yang sejenis.

Pada kebanyakan orang, perilaku pembelian konsumen seringkali diawali dan dipengaruhi oleh banyaknya rangsangan (stimulli) dari luar dirinya, baik berupa rangsangan pemasaran maupun rangsangan dari lingkungannya. Rangsangan tersebut kemudian diproses dalam diri sesuai dengan karakteristik pribadinya, sebelum akhirnya diambil keputusan pembelian. Karakteristik pribadi konsumen yang dipergunakan untuk memproses rangsangan tersebut sangat komplek dan salah satunya adalah motivasi untuk membeli.

Minat beli ulang merupakan minat pembelian yang didasarkan atas pengalaman pembelian yang telah dilakukan di masa lalu. Minat beli ulang yang tinggi mencerminkan tingkat kepuasan yang tinggi dari konsumen ketika memutuskan untuk mengadopsi suatu produk. Keputusan untuk mengadopsi atau menolak suatu produk timbul setelah konsumen mencoba suatu produk tersebut dan kemudian timbul rasa suka atau tidak suka terhadap produk tersebut. Rasa suka terhadap produk timbul bila konsumen mempunyai persepsi bahwa produk yang mereka gunakan berkualitas baik dan dapat memenuhi atau bahkan melebihi keinginan dan harapan konsumen. Dengan kata lain, produk tersebut memiliki nilai yang tinggi di mata konsumen. Tingginya minat beli ulang ini akan membawa dampak yang positif terhadap keberhasilan produk di pasar (Thamrin, 2003). 


\section{Kerangka Pemikiran}

Berdasarkan hasil telaah pustaka mengenai faktor-faktor yang mempengaruhi loyalitas konsumen, maka dikembangkanlah kerangka pemikiran teoritis yang mendasari penelitian ini seperti yang dilihat pada gambar berikut :

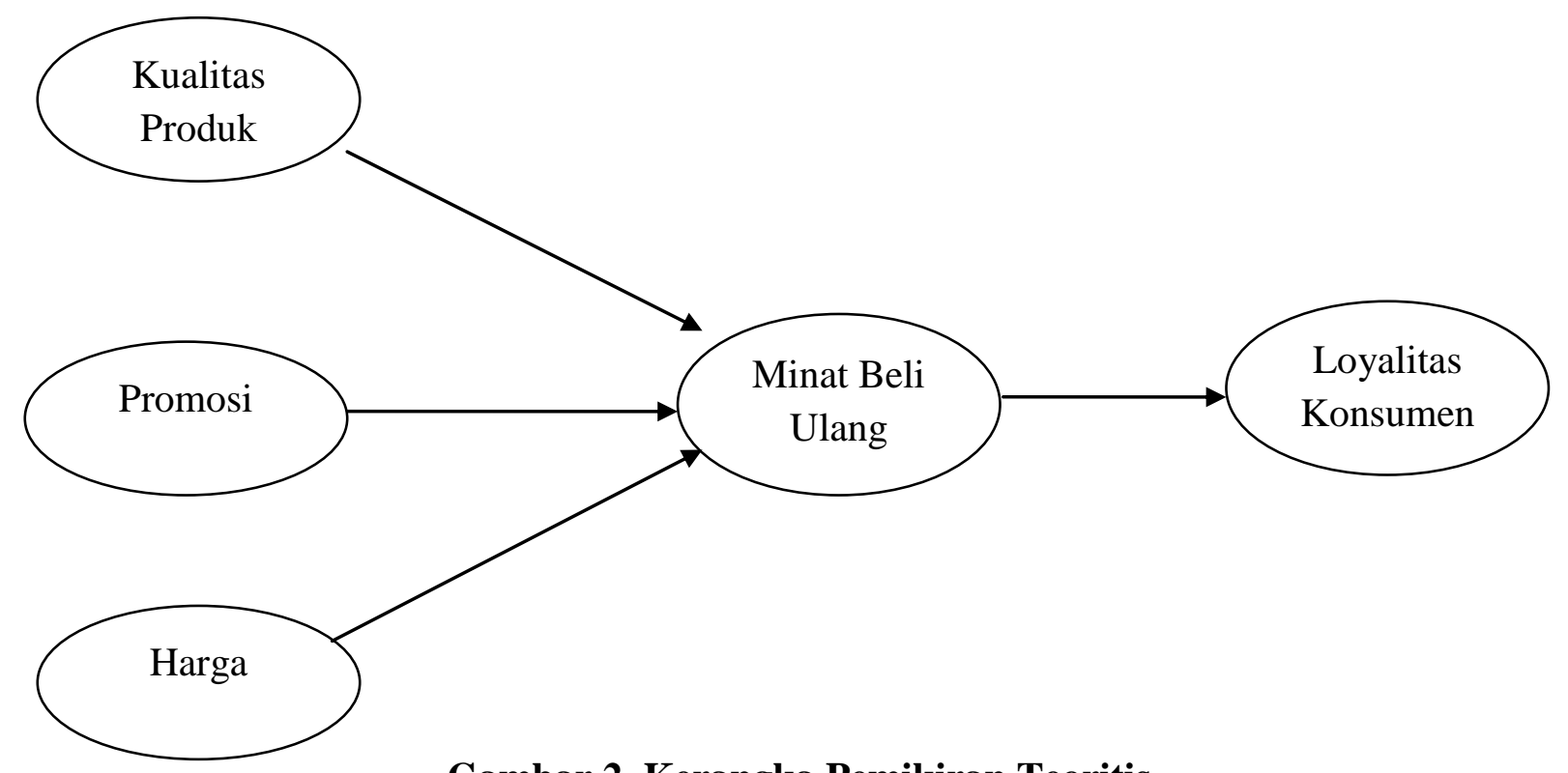

Gambar 2. Kerangka Pemikiran Teoritis

\section{METODOLOGI PENELITIAN}

\section{Variabel Penelitian dan Definisi Operasional}

Kualitas produk adalah ukuran relatif You C 1000 yang dapat memberikan gambaran mengenai seberapa jauh tingkat keunggulan suatu produk mampu memenuhi keinginan konsumen. Indikator kualitas produk antara lain: Aman dikonsumsi, kesan kualitas dan cita rasa (Cahya dan Simanjuntak, 2012)

Promosi merupakan suatu bentuk komunikasi pemasaran yang dilakukan oleh perusahaan You C 1000. Indikator promosi antara lain: pemberian potongan harga, iklan serta pemberian hadiah, bonus dan kupon (Assaury, 2004).

Harga adalah jumlah uang yang dibutuhkan untuk memperoleh You C 1000. Indikator harga antara lain: harga terjangkau, harga bersaing dan harga sesuai kualitas (Prasetio, 2012).

Minat beli ulang adalah minat pembelian terhadap minuman You C 1000 yang didasarkan atas pengalaman pembelian yang telah dilakukan di masa lalu. Indikator minat beli ulang antara lain: kebutuhan akan produk, keinginan membeli ulang dan ketertarikan untuk tetap menggunakan (Ferdinand, 2006)

Loyalitas adalah pengambilan keputusan untuk melakukan pembelian secara terusmenerus terhadap You C 1000. Indikator loyalitas antara lain: pembelian minuman secara berulang, menambah jumlah pembelian, rekomendasi kepada pihak atau konsumen lain dan menceritakan hal-hal positif (Palilati 2004)

\section{Populasi dan Sampel}

Adapun yang menjadi populasi dalam penelitian ini adalah konsumen You C 1000 di Semarang. Teknik pengambilan sampel yang digunakan adalah dengan teknik purposive sampling yang merupakan teknik pengambilan sampel berdasarkan kriteria tertentu yang ditentukan oleh peneliti, kriteria sampel yang digunakan adalah responden yang pernah mengkonsumsi You C 1000 lebih dari satu kali. 
Dewi Sartika : Analisis Faktor-Faktor Yang Mempengaruhi Minat Beli Ulang Produk You C 1000 Serta Dampaknya Terhadap Loyalitas Konsumen

\section{Teknik Analisis Data}

Metode analisis yang dipilih untuk menganilisis data adalah SEM ( Structural Equation Model ). Pengujian hipotesis menggunakan alat analisis data Structural Equation Modeling dari paket statistik AMOS 7 sebagai sebuah model persamaan struktur, AMOS sering digunakan dalam penelitian-penelitian pemasaran dan manajemen strategik (Bacon dalam Ferdinand 2006 ).

\section{HASIL DAN PEMBAHASAN}

\section{Analisis Structural Equation Modelling}

Analisis selanjutnya adalah analisis Structural Equation Modelling (SEM) secara full model, setelah dilakukan analisis terhadap tingkat unidimensionalitas dari indikator-indikator pembentuk variabel laten yang diuji dengan confirmatory factor analysis. Analisis hasil pengolahan data pada tahap full model SEM dilakukan dengan melakukan uji kesesuaian dan uji statistik. Hasil pengolahan data untuk analisis full model SEM ditampilkan sebagai berikut

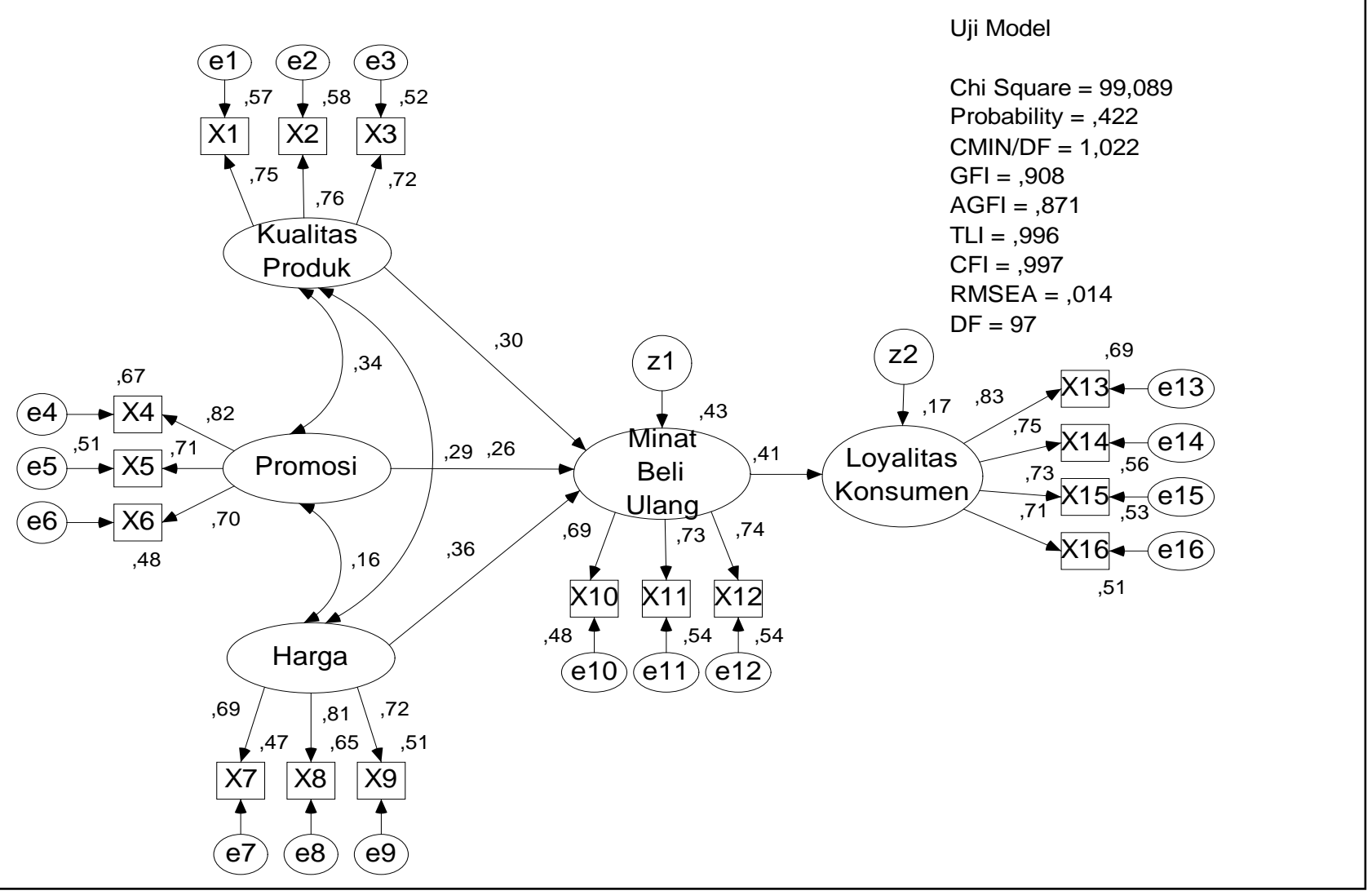

\section{Gambar 3. Hasil Pengujian Full Model SEM}

Uji terhadap kelayakan model menunjukkan bahwa model ini sesuai dengan data atau fit terhadap data yang digunakan dalam penelitian adalah seperti telihat pada tabel berikut ini : 
Tabel 2. Hasil Pengujian Kelayakan Model SEM

\begin{tabular}{cccc}
\hline $\begin{array}{c}\text { Goodness of Fit } \\
\text { Indeks }\end{array}$ & Cut-off Value & Hasil Analisis & Evaluasi Model \\
\hline Chi - Square & Diharapkan kecil & 99.089 & Baik \\
Probability & $\geq 0.05$ & 0.422 & Baik \\
CMINDF & $\leq 2.00$ & 1.022 & Baik \\
GFI & $\geq 0.90$ & 0.908 & Baik \\
AGFI & $\geq 0.90$ & 0.871 & Marginal \\
TLI & $\geq 0.95$ & 0.996 & Baik \\
CFI & $\geq 0.95$ & 0.997 & Baik \\
\hline RMSEA & $\leq 0.08$ & 0.014 & Baik \\
\hline
\end{tabular}

Hasil analisis pengolahan data terlihat bahwa semua konstruk yang digunakan untuk membentuk sebuah model penelitian, pada proses analisis full model SEM telah memenuhi kriteria goodness of fit yang telah ditetapkan. Nilai probability pada analisis ini menunjukkan nilai diatas batas signifikansi yaitu sebesar $0,422(\mathrm{p}>0.05)$. Nilai ini menunjukkan tidak adanya perbedaan antara matriks kovarian prediksi dengan matriks kovarian yang diestimasi. Ukuran goodness of fit lain juga menunjukkan pada kondisi yang baik. Untuk mendapatkan model yang baik, akan terlebih dahulu diuji masalah penyimpangan terhadap asumsi SEM.

Tabel 3. Standardized Regression Weight

\begin{tabular}{|c|c|c|c|c|c|c|c|}
\hline & & & Estimate & S.E & C.R & $\mathbf{P}$ & Label \\
\hline Minat_Beli_Ulang & $<--$ & Kualitas_Produk &, 300 & , 124 & $\begin{array}{r}2,42 \\
7\end{array}$ & ,015 & \\
\hline Minat_Beli_Ulang & $<---$ & Harga & ,373 & , 124 & $\begin{array}{r}3,00 \\
4\end{array}$ &, 003 & \\
\hline Minat_Beli_Ulang & $<--$ & Promosi & ,285 & , 125 & $\begin{array}{r}2,27 \\
0\end{array}$ &, 023 & \\
\hline $\begin{array}{l}\text { Loyalitas_Konsu } \\
\text { men }\end{array}$ & $<--$ & Minat_Beli_Ulang & ,457 &, 130 & $\begin{array}{r}3,52 \\
6\end{array}$ & $* * *$ & \\
\hline $\mathbf{X} 2$ & $<---$ & Kualitas_Produk & 1,032 &, 154 & $\begin{array}{r}6,69 \\
7\end{array}$ & $* * *$ & \\
\hline X6 & $<--$ & Promosi & 1,000 & & & & \\
\hline X5 & $<--$ & Promosi & 1,037 &, 166 & $\begin{array}{r}6,23 \\
6\end{array}$ & $* * *$ & \\
\hline $\mathbf{X 4}$ & $<---$ & Promosi & 1,144 & , 179 & $\begin{array}{r}6,40 \\
7\end{array}$ & $* * *$ & \\
\hline X9 & $<---$ & Harga & 1,000 & & & & \\
\hline X8 & $<---$ & Harga & 1,059 & , 165 & $\begin{array}{r}6,41 \\
4\end{array}$ & $* * *$ & \\
\hline $\mathbf{X 7}$ & $<---$ & Harga & 1,031 &, 169 & $\begin{array}{r}6,12 \\
1\end{array}$ & $* * *$ & \\
\hline $\mathbf{X 1 2}$ & $<---$ & Minat_Beli_Ulang & 1,000 & & & & \\
\hline X11 & $<--$ & Minat_Beli_Ulang & 1,098 &, 169 & $\begin{array}{r}6,48 \\
1\end{array}$ & $* * *$ & \\
\hline $\mathbf{X 1 3}$ & $<--$ & Loyalitas_Konsumen & 1,000 & & & & \\
\hline X14 & $<--$ & Loyalitas_Konsumen & ,958 & , 118 & $\begin{array}{r}8,08 \\
2\end{array}$ & $* * *$ & \\
\hline
\end{tabular}


Dewi Sartika : Analisis Faktor-Faktor Yang Mempengaruhi Minat Beli Ulang Produk You C 1000 Serta Dampaknya Terhadap Loyalitas Konsumen

\begin{tabular}{|c|c|c|c|c|c|c|}
\hline $\mathbf{X} 15$ & $<---$ & Loyalitas_Konsumen & ,918 &, 117 & $\begin{array}{r}7,83 \\
3\end{array}$ & $* * *$ \\
\hline X16 & $<---$ & Loyalitas_Konsumen & ,774 &, 101 & $\begin{array}{r}7,64 \\
6\end{array}$ & $* * *$ \\
\hline $\mathbf{X 1 0}$ & $<---$ & Minat_Beli_Ulang & ,921 &, 148 & $\begin{array}{r}6,23 \\
0\end{array}$ & $* * *$ \\
\hline $\mathbf{X 3}$ & $<---$ & Kualitas_Produk & ,993 &, 152 & $\begin{array}{r}6,54 \\
0\end{array}$ & $* * *$ \\
\hline $\mathbf{X} 1$ & $<---$ & Kualitas_Produk & 1,000 & & & \\
\hline
\end{tabular}

\section{Pengujian Hipotesis}

Setelah semua asumsi dapat dipenuhi, selanjutnya akan dilakukan pengujian hipotesis sebagaimana diajukan pada bab sebelumnya. Pengujian 5 hipotesis penelitian ini dilakukan berdasarkan nilai Critical Ratio (CR) dari suatu hubungan kausalitas dari hasil pengolahan SEM sebagaimana pada tabel 4 berikut.

Tabel 4. Regression Weight Structural Equation Modelling

\begin{tabular}{lllrllll}
\hline & & & Estimate & S.E & C.R & P & Label \\
\hline Minat_Beli_Ulang & $<---$ & Kualitas_Produk &, 300 &, 124 & 2,427 &, 015 & \\
Minat_Beli_Ulang & $<---$ & Harga &, 373 &, 124 & 3,004 &, 003 & \\
Minat_Beli_Ulang & $<---$ & Promosi &, 285 &, 125 & 2,270 &, 023 & \\
Loyalitas_Konsumen & $<---$ & Minat_Beli_Ulang &, 457 &, 130 & 3,526 & $* * *$ & \\
\hline
\end{tabular}

Hubungan antara kualitas produk terhadap minat beli ulang menunjukkan nilai CR (Critical Ratio) sebesar 2,427 dengan P (probability) sebesar 0,015. Hal ini berarti bahwa kualitas produk berpengaruh signifikan terhadap minat beli ulang dan telah memenuhi syarat karena nilai CR di atas 1,96 dan probabilitas di bawah 0,05.

Hasil pengolahan data menunjukkan nilai CR (Critical Ratio) di atas 1,96 dan P (probability) di bawah 0,05. Pada tabel standardized regression weight dapat dilihat bahwa nilai CR sebesar 2,270 dengan nilai $\mathrm{P}$ sebesar 0,023. Hal ini berarti bahwa promosi berpengaruh signifikan terhadap minat beli ulang.

Berdasarkan hasil pengolahan data standardized regression weight diketahui bahwa nilai CR (Critical Ratio) sebesar 3,004 dengan nilai P (probability) sebesar 0,003. Kedua nilai ini menunjukkan hasil yang memenuhi syarat, yaitu di atas 1,96 untuk CR dan di bawah 0,05 untuk nilai P. Hal ini berarti bahwa harga berpengaruh signifikan terhadap minat beli ulang.

Berdasarkan data hasil pengolahan data standardized regression weight diketahui bahwa nilai CR (Critical Ratio) sebesar 3,526 dengan nilai P (probability) sebesar 0,000. Kedua nilai ini menunjukkan hasil yang memenuhi syarat, yaitu nilai CR di atas 1,96 dan nilai $\mathrm{P}$ di bawah 0,05 . Hal ini berarti bahwa minat beli berpengaruh signifikan terhadap loyalitas konsumen

\section{Pembahasan}

Hasil analisis dengan menggunakan Structural Equation Modelling (SEM) ditunjukkan sebagai berikut :

1. Pengaruh Kualitas Produk terhadap Minat Beli Ulang 
Dari hasil statistik membuktikan bahwa ada pengaruh yang positif dan signifikan antara kualitas produk dengan minat beli ulang yang artinya semakin baik kualitas produk You C 1000 maka minat beli ulang semakin tinggi juga. Variabel kualitas produk You C 1000 menunjukkan pengaruh positif terhadap minat beli ulang, yang ditunjukkan dengan nilai estimate yang ada sebesar 0,300 .

Indikator-indikator dari kualitas produk yang terdiri dari You C 1000 aman dikonsumsi, kesan kualitas produk You C 1000, dan cita rasa produk. Sedangkan indikator minat beli ulang dibentuk oleh kebutuhan akan produk, keinginan membeli ulang, dan ketertarikan untuk tetap menggunakan.

Indikator-indikator tersebut berdasarkan jurnal dan dikembangkan sesuai dengan penelitian. Dari hasil analisis SEM diketahui bahwa indikator kesan kualitas produk tersebut merupakan indikator paling dominan dari kualitas produk terhadap minat beli ulang. Hal ini berarti bahwa ketika kualitas produk yang dihasilkan dapat dipercaya oleh konsumen yang dapat mempengaruhi minat beli ulang pada produk You C 1000.

2. Pengaruh Promosi terhadap Minat Beli Ulang

Dari hasil statistik membuktikan bahwa ada pengaruh yang positif dan signifikan antara promosi dengan minat beli ulang yang artinya semakin menarik promosi yang dilakukan oleh perusahaan You C 1000 maka minat beli ulang juga semakin meningkat. Variabel promosi You C 1000 menunjukkan pengaruh positif terhadap minat beli ulang, yang ditunjukkan dengan nilai estimate yang ada sebesar 0,285.

Indikator-indikator dari promosi yang terdiri dari pemberian potongan harga, iklan, dan pemberian hadiah. Sedangkan indikator minat beli ulang dibentuk oleh kebutuhan akan produk, keinginan membeli ulang, dan ketertarikan untuk tetap menggunakan.

Indikator-indikator tersebut berdasarkan jurnal dan dikembangkan sesuai dengan penelitian. Dari hasil analisis SEM diketahui bahwa indikator iklan merupakan indikator paling dominan dari promosi terhadap minat beli ulang. Hal ini berarti bahwa promosi berupa informasi dan gambaran mengenai produk You C 1000 pada beberapa media dapat mempengaruhi minat beli konsumen. Selain itu juga iklan You C 1000 yang dibintangi Miss Universe juga bisa menarik minat beli konsumen.

3. Pengaruh Harga terhadap Minat Beli Ulang

Dari hasil statistik membuktikan bahwa ada pengaruh yang positif dan signifikan antara harga dengan minat beli ulang yang artinya semakin terjangkau harga produk You C 1000 maka minat beli ulang juga akan semakin tinggi. Variabel harga You C 1000 menunjukkan pengaruh positif terhadap minat beli ulang, yang ditunjukkan dengan nilai estimate yang ada sebesar 0,373.

Indikator-indikator dari harga yang terdiri dari harga yang terjangkau, harga bersaing dengan merek lain, dan kesesuaian harga dengan kualitas. Sedangkan indikator minat beli ulang dibentuk oleh kebutuhan akan produk, keinginan membeli ulang, dan ketertarikan untuk tetap menggunakan.

Indikator-indikator tersebut berdasarkan jurnal dan dikembangkan sesuai dengan penelitian. Dari hasil analisis SEM diketahui bahwa indikator tingkat harga dengan merek pesaing merupakan indikator paling dominan dari harga produk terhadap minat beli ulang. Hal ini berarti bahwa ketika harga You C 1000 lebih tinggi daripada harga produk pesaingnya dapat mempengaruhi minat beli ulang pada produk You C 1000.

4. Pengaruh Minat Beli Ulang terhadap Loyalitas Konsumen

Dari hasil statistik membuktikan bahwa ada pengaruh yang positif dan signifikan antara minat beli ulang dengan loyalitas konsumen yang artinya semakin tinggi minat beli ulang konsumen terhadap produk You C 1000 maka akan menciptakan loyalitas konsumen. Variabel minat beli ulang You C 1000 menunjukkan pengaruh positif terhadap loyalitas konsumen, yang ditunjukkan dengan nilai estimate yang ada sebesar 0,457. 
Dewi Sartika : Analisis Faktor-Faktor Yang Mempengaruhi Minat Beli Ulang Produk You C 1000 Serta Dampaknya Terhadap Loyalitas Konsumen

Indikator-indikator dari minat beli ulang yang terdiri dari kebutuhan akan produk, keinginan membeli ulang, dan ketertarikan untuk tetap menggunakan. Sedangkan indikator loyalitas konsumen dibentuk oleh pembelian secara berulang, menambah jumlah pembelian, merekomendasikan kepada konsumen lain dan menceritakan hal-hal positif.

Indikator-indikator tersebut berdasarkan jurnal dan dikembangkan sesuai dengan penelitian. Dari hasil analisis SEM diketahui bahwa indikator ketertarikan untuk tetap menggunakan merupakan indikator paling dominan dari minat beli ulang terhadap loyalitas konsumen. Dalam hal ini, konsumen tetap tertarik membeli produk You C 1000 secara berulang yang akan menunjukkan bahwa sudah terciptanya suatu kepuasan konsumen dan menjadikan konsumen loyal.

\section{SIMPULAN}

Berdasarkan hasil pengolahan data, maka diperoleh simpulan sebagai berikut: kualitas produk, promosi dan harga berpengaruh positif dan signifikan terhadap minat beli ulang produk minuman You C 1000. Minat beli ulang berpengaruh positif dan signifikan terhadap loyalitas konsumen You C 1000.

Saran-saran yang bisa diberikan adalah sebagai berikut perusahaan You C 1000 tetap mempertahankan kualitas produk dan juga menciptakan inovasi-inovasi terbaru dengan menambahkan varian rasa yang baru misalnya rasa jeruk nipis, jeruk sunkist, jeruk bali atau buah-buah yang kaya akan vitamin $\mathrm{C}$ sehingga akan menarik konsumen untuk melakukan pembelian ulang. Jika perusahaan You C 1000 ingin menaikkan tingkat harga agar citra produk dan perusahaan meningkat maka perusahaan perlu memperhatikan faktor-faktor seperti peningkatan kualitas produk ke arah yang lebih baik lagi yang sesuai dengan tingkat harg anya. Konsumen selalu tertarik untuk membeli minuman You C 1000 untuk itu perusahaan dapat menginformasikan dan menekankan pada konsumen tentang manfaat dari You C 1000 dengan mengadakan talkshow bersama pakar vitamin C dan juga memberikan sample You C 1000 agar konsumen tertarik untuk melakukan pembelian ulang secara terus menerus agar menjadi konsumen yang semakin loyal.

\section{DAFTAR PUSTAKA}

Alma, Buchari. 2004. Manajemen Pemasaran dan Pemasaran Jasa (Edisi Revisi). Bandung: CV. Alfabeta.

Assaury. 2004. Manajemen Pemasaran. Jakarta: PT Gramedia Pustaka Utama.

Boyd, Walker dan Larrenche. 2000. Manajemen Pemasaran : Suatu Pendekatan Strategis dengan Orientasi Global (Jilid 1). Jakarta: Erlangga

Fakhru, Muhammad dan Hanifa Yasin. 2014. Pengaruh Promosi dan Harga terhadap Minat Beli Perumahan Obama PT Nailah Adi Kurnia Sei Mencirim Medan. Jurnal Manajemen dan Bisnis. 14(2): 135-143

Ferdinand, Augusty. 2006. Structural Equation Modeling Dalam Penelitian Manajemen. Semarang: Badan Penerbit Universitas Diponegoro

F, Yohana dan Sahat Simanjuntak. 2012. Faktor yang Mempengaruhi Minat Beli Produk Makanan dan Minuman Usaha Kecil Menengah Kabupaten Tangerang. Jurnal Manajemen dan Kewirausahaan. 14 (2): 164-172

Hurriyati, Ratih. 2005. Bauran Pemasaran dan Loyalitas Konsumen. Bandung: CV. Alfabeta. Iwan, Suryono, Bambang. 2008. Analisis Faktor-faktor yang Mempengaruhi Minat Beli Ulang Produk serta Dampaknya terhadap Loyalitas Pelanggan. http://eprints.undip.ac.id/14877/

Kotler, Philip, dan Gary Armstrong. 2008. Prinsip-prinsip Pemasaran (Jilid 1). Jakarta: Erlangga 
Kotler, Philip dan Kevin Lane Keller. 2009. Manajemen Pemasaran (Jilid 1). Jakarta: Erlangga

Education . 2012. Manajemen Pemasaran. New Jersey : Pearson

Lamb, Hair, McDaniel. 2001. Pemasaran (Jilid 1). Jakarta: Salemba Empat

Lupiyoadi, Rambat. 2001. Manajemen Pemasaran Jasa Teori dan Praktik. Jakarta: Salemba Empat.

Kristiana, Nela dan Nanang Wahyudin. 2012. Pengaruh Persepsi Atribut Produk terhadap Minat Beli Konsumen Mobil Merek ISUZU ELF Studi pada PT Karya Zirang Utama Isuzu Semarang. Jurnal Ilmu Manajemen dan Akuntansi Terapan, 3(1): 1-9

Nasir, Mocch. 2007. Studi Perilaku Konsumen terhadap Keputusan Pembelian Air Minum Aqua di Kota Surakarta. Jurnal Manajemen dan Bisnis. 12(1): 29-43

Palilati, Alida. 2004. Pengaruh Tingkat Kepuasan terhadap Loyalitas Nasabah Tabungan Perbankan di Wilayah Etnik Bugis . Analisis. 1(2): 65-74

Prasetio, Ari. 2012. Pengaruh Kualitas Pelayanan dan Harga terhadap Kepuasan Pelanggan. Management Analysis Journal. Semarang: Universitas Negeri Semarang

Rizana, Anggitan. 2013. Analisis Pengaruh Kualitas Produk, Harga dan Promosi terhadap Loyalitas Pelanggan dengan Minat Beli Ulang sebagai Variabel Intervening. http://eprints.dinus.ac.id/8860/

Sekaran, Uma. 2006. Research Methods For Business, Metodologi Penelitian Untuk Bisnis (Jilid 2). Jakarta: Salemba Empat

Sugiyono. 2013. Metode Penelitian Pendidikan: Pendekatan Kuantitatif, Kualitatif dan R\&D. Bandung: CV. Alfabeta.

Sularko, Jaka. 2004. Pengaruh Atribut Toko terhadap Minat Beli Konsumen pada Swalayan Sami Makmur Palur Karanganyar. http://eprints.ums.ac.id/137/Artikel_Jaka_Sularko.doc

Tjiptono, Fandy dan Chandra Gregorius. 2008. Pemasaran Startegik. Yogyakarta: CV. Andi Offset.

Ujianto, Abdurachman. 2002. Analisis Faktor-faktor yang Menimbulkan Minat Beli Konsumen Sarung. Jurnal Manajemen dan Kewirausahaan. 6 (1): 34-53 http://youc1000.com 